AT-TAJDID: Jurnal Pendidikan Dan Pemikiran Islam

(p-ISSN: 2548-5784 |e-ISSN: 2549-2101)

Vol. (5) (01), (Januari-Juni) (2021), (93-109)

Doi: http://dx.doi.org/10.24127/att.v5i01.1599

\title{
NILAI NILAI PENDIDIKAN MULTIKULTURAL DALAM PERSPEKTIF TAFSIR AL-AZHAR KARYA BUYA HAMKA
}

\author{
Ivatul Mukarromah ${ }^{1}$ \\ Institut Agama Islam Negri (IAIN) Metro Lampung \\ ivahalifah@gmail.com \\ Buyung Syukron ${ }^{2}$ \\ Institut Agama Islam Negeri (IAIN) Metro, Lampung \\ buyungsyukron@gmail.com \\ Isti Fathonah ${ }^{3}$ \\ Institut Agama Islam Negeri (IAIN) Metro, Lampung \\ istifathonah@gmail.com
}

\begin{abstract}
ABSTRAK
Dalam tulisan ini bertujuan menghadirkan problematika dan solusi pendidikan dalam wacana pendidikan multikultural yang dianalisa serta dikembangkan melalui pengkajian konsep serta nilai pendidikan multikultural dalam Al-Quran dengan perspektif tafsir Al-Azhar karya Buya Hamka. Metode pengkajian mengunakan kajian library riset atau kepustakaan dengan metode deskriptif kualitatif dan pendekatan tafsir maudu'i/tematik karna bersinggungan dengan kajian Al-Quran. Hasil penelitian menunjukan pada Qs. Al-Hujurat ayat 11-13 meng-intepretasi akan pendidikan multikultural berupa nilai-nilai pendidikan multikultural yakni: 1)Nilai Perdamaian, 2)Nilai Inklusivisme, 3)Nilai Kearifan, 4)Nilai Toleransi, 5)Nilai Humanisme.
\end{abstract}

Kata Kunci: Nilai, Pendidikan Multikultural, Hamka, Al-Quran

\begin{abstract}
This paper aims to present educational problems and solutions in the discourse of multicultural education which are analyzed and developed through the study of the concepts and values of multicultural education in the Al-Quran with the perspective of Buya Hamka's Al-Azhar interpretation. The study method uses a research library or literature study with a qualitative descriptive method and a maudu'i / thematic interpretation approach because it intersects with the study of the Koran. The research results show the Qs. Al-Hujurat verses 11-13 interpret multicultural education in the form of multicultural education values, namely: 1) Value of Peace, 2) Value of Inclusivism, 3) Value of Wisdom, 4) Value of Tolerance, 5) Value of Humanism.
\end{abstract}

Keywords: Multicultural Education, Hamka, Al-Quran 


\section{A. PENDAHULUAN}

Indonesia adalah negara multikultural terbesar di dunia, hal ini dibuktikan dengan keberagaman yang terbentang dari ujun Sabang sampai dengan Merauke dari berbagai kemajemukan dalam pelbagai bidangnya baik dalam sudut kultur geografis, agama, budaya, bahasa, sosial, dan masyarakatnya (Tulus 2014; Syafutra, et al., 2021). Kemajemukan adalah niscaya dan anugrah bagi bangsa Indonesia sebagai bangsa yang kaya, namun disamping itu keberagaman yang ada diakui atau tidak apabila tidak dapat dirawat dengan baik dan bijak menjadi problematika yang menimbulkan berbagai banyak konflik, dan pergesekan. Sebagaimana yang dinukil dari kabar harian kompas, sejak 14 tahun setelah reformasi tercatat kasus kekerasan dan diskriminasi sebanyak 2.398 kasus di Indonesia yang dilatar belakangi oleh kemajemukan yang ada, $60 \%$ dilatar belakangi oleh kemajemukan Agama, 20\% dilatar belakangi kemajemukan etnis, $15 \%$ gender dan $5 \%$ persen sisanya kekerasan seksual.(Welianto, 2020) Berdasarkan hal ini kemajemukan Agama menduduki persentasi tertinggi yang melatar belakangi hadirnya konflik.

Kemajemukan bangsa Indonesia berdasarkan kepercayaan atau agama terdiri dari enam agama besar yakni Islam, Kristen, Katolik, Hindu, Budha, dan Khong $\mathrm{Hu} \mathrm{Cu}$. Berdasrkan data statistik per tahun 2010 tercatat pemeluk agama Islam sebanyak 207,2 juta jiwa (87,18\%), pemeluk agama Kriten sebanyak 16,5 juta jiwa (6,96\%), pemeluk agama Katolik sebanyak 6,9 juta jiwa (2,91\%), pemeluk agama Hindu sebanyak 4.012.116 jiwa $(1,69 \%)$, pemeluk agama Budha sebanyak 1.703.254 jiwa $(0,72 \%)$ dan pemeluk agama Khong $\mathrm{Hu} \mathrm{Cu}$ sebanyak 117,1 jiwa
$(0,05 \%)$ dari jumblah penduduk Indonesia. (Badan Pusat Statistik, 2010). Berdasarkan data ststistik tersebut Agama Islam sebagai agama mayoritas yang dianut bangsa Indonesia menjadi kajian yang sangat menarik untuk dapat menilik kontribusi umat muslim sebagai penduduk mayoritas dalam meredupkan berbagai konflik dan pergesekan selama ini. Dalam agama Islam yang serat dan padat akan nilai nilai tidak menutup mata dengan keberagaman dan kemultikultural yang dipandang dalam AlQuran adalah sebuah keniscayaan Tuhan dengan landasan dan maksud agar terciptanya manusia yang damai dan mampu melaksanakan tugasnya di muka bumi baik sebagai abdullah dan khalifatulah.(QS. Al-Hujurat :13)

Multikultural bukanlah suatu yang baru, jauh dari 15 Abad Islam telah menyadarkan melalui tauladan Rasululah SAW bagaiman membina masyarakat yang beragam dengan tetap hidup berdampingan, kedamaiaan dengan penuh toleran. Begitu halnya Multikultural bukanlah suatu yang baru, kesadaran multikultural bangsa Indonesia sudah ada dan diterapkan oleh para pendiri bangsa Indonesia untuk mendesain keberagaman bangsa Indonesia dengan semboyanya "BHINEKA TUNGGAL IKA". Acuan utama agar terwujudnya masyarakat Indonesia yang rukun dalam ke-multikultural yang ada adalah multikulturalisme, yakni sebuah ideologi yang mengakui dan mengagungkan perbedaan dalam kesederajatan baik secara individu maupun secara kebudayaan (Siyono, 202; Suparlan, 2015) Dan dalam mewujutkan masyarakat multukultural yang menekankan keanekaragaman dalam kesederajatan perlunya suatu upaya yang hanya mungkin terwujut apabila: 1) Konsep Multikultural Menyebar luas dan difahami pentingnya 
bagi bangsa Indonesia, serta adanya keinginan baik tingkat nasional maupun lokal untuk mengadopsi dan menjadi pedoman hidup, 2) Kesamaan paham antar para ahli mengenai pengertian multikulturalisme dan bangunan konsep yang mendukungnya, serta 3) Upaya-upaya yang dapat dilakukan untuk mewujudkannya.( Suparlan, 2015)

$$
\text { Dalam upaya pewujudkan }
$$

keanekaragaman dalam kesederajatan dan penuh toleransi dan perdamaiaan, pendidikan dirasa menjadi sarana yang tepat yang dipercaya sebagai alat yang fundamental untuk transformasi kultur budaya dan menumbuh kembangkan peradaban masyarakat. Dengan ini pendidikan laksana pabrik sumber daya manusia danlam transformasi nilai nilai menuju manusia yang unggul dan bermartabat dengan nilai nilai kemanusiaan dan kebudayaan, benar menjadi refleksi awal hadirnya pendidikan multikultural dalam kulikurum pendidikan dan ikut mengatur dalam konsep pengembangan pendidikan upaya menyiapkan generasi penerus yang menjunjung tinggi idiologi multikulturalisme.

Dengan pendidikan Islam dimana AlQuran adalah landasan dalam perkembangan baik dalam sistem sampai dengan kurikulum dan pelaksanaannya, AlQuran pun telah banyak menyingkap akan kemultikulturan manusia yang merupakan bagian dari sunatullah yang tidak akan dapat terpisahkan dalam kehidupan manusia. Ayat ayat multikultural telah banyak ditemukan diantaranya dalam Qs. Al-Baqoroh:105, Al-Maidah:48, Al-Anfal: 160, Al-Hujurot:11-13, Al-Anbiyaa:107, dan masih banyak lagi ayat ayat yang menyinggung dan senada dengan ayat tersebut.(Sulalah, 2017).
Di Indonesia dimana mayoritas masyarakatnya adalah umat Islam maka bukan manjadi suatu yang kebetulan dengan Indonesia sebagai negara berpenduduk Islam terbesar di dunia menjadi suatu hal yang menarik untuk dapat dikaji secara mendalam akan peranan dan kontribusi umat Islam di Indonesia dalam meredupkan konflik akibat bersinggungan dengan keberagaman melalui refleksi dunia pendidikan Islam dengan berbasik multikultural. Sehingga dalam kajian singkat ini akan diarahkan dalam kajian pendidikan multikultural dalam Al-Quran yang diintepretasikan melalui Tafsir Al-Azhar karya Buya Hamka sebagai sosok mufasir Indonesia sekaligus ulama yang menyandang gelar Pahlawan Nasional Indonesia dan yang ikut berperan aktif dalam sumbangsih pemikirannya di dunia pendidikan.

Kajian diawali dari penjelasan Multikulturalisme dan pendidikan Multikultural di Indonesia, dilanjutkan dengan analisis dan penjelasan data yang diambil dari analisa ayat ayat multikultural yakni QS. Al-Hujurat Ayat 11-13 dalam tafsir Al-Azhar karya Buya Hamka. Analisa terhadap ayat multikultural tersebut kemudian dilanjutkan dengan interprestasi Ayat akan nilai-nilai pendidikan Islam berkarakter Multikultural yang bersandarkan oleh Al-Quran dan keIndonesiaan.

\section{B. METODOLOGI}

Metode penelitian yang digunakan dalam penelitian ini adalah metode penelitian kualitatif dengan jenis penelitian pustaka (library research) denggan menggunakan metode deskriptif kualitatif dan denggan pendekatan tafsir maudu'i (tematik). Mengunakan pendekatan dan 
metode tafsir maudu'i atau tematik, yakni suatu metode yang menjelaskan kandungan Al-Quran dengan menghimpun seluruh ayat ayat Al-Quran yang membahas tema pendidikan Multikultural dan selaras dengan penelitian ini walau waktu, tempat dan asbab turunnya berbeda. ( Al-Farmawi, 2012) Dalam Peneliti ini akan mengungkap nilai- nilai pendidikan multikultural yang dapat digali dalam Al-Quran Surat AlHujurat ayat 11-13 dengan mengunakan pendekatan dan jenis penelitian tersebut. Sehingga langkah utama dalam penelitian ini adalah pengumpulan data yakni dokumentasi dari berbagai sumber dalam penelitian dari sumber perimer berupa AlQuran dan tarjamah serta kitab tafsir AlAzhar karya Buya Hamka dan sumber data sekunder yakni buku, jurnal dan makalah yang telah diseminarkan yang menunjang terkait Pendidikan Multikultural dan bukubuku karya Buya Hamka yang membantu proses penelitian. Analisis data kualitatif adalah dengan menata, menyusun dan memberi makna pada kumpulan data. (Sabarguna S. 20014) Sehingga dalam penelitian ini penulis mengunakan beberapa teknis analisis data secara persial yakni analisis isi dan triangulasi sebagai cross-check keabsahan data.

\section{HASIL DAN PEMBAHASAN} 1. Dinamika Multikulturalisme di
Indonesia

Memahami multikulturalisme sama halnya memaknai kembali pedoman dan idiom bangsa Indonesia yakni "Bhinneka Tunggal Ika" yang memiliki arti berbeda beda tapi tetap satu jua. Multikulturalisme kerap kali disamakan dengan makna pluralisme, yang secara definisi dan makna jelaslah berbeda namun dalam membangun dan memaknai akan idiom bangsa ini yakini "Bhinneka Tunggal Ika" adalah menyandingkan pentingnya memahami pluralisme dan multikulturalisme. Secara sederhana Multikulturalisme adalah sebuah filosofi yang kerap kali disebut sebagai idiologi yang mengakui dan menghendaki kesederajatan dalam keberagaman atau pluralitas yang ada. yakni suatu Idiologi yang mengakui dan mengagungkan pluralitas dalam kesederajatan baik secara individu maupun secara kebudayaan dalam bentuk toleransi dalam membina suatu dunia baru. (Rahmat, 2019). Sedangkan plurasime adalah sebuah paham yang memberikan ruang dan kerangka untuk kebeberagaman sebagai salah satu entitas yang mendasar dari kemanusiaan manusia. (Suparlan, 2001) Sehingga multikulturalisme tidak dapat disamakan dengan makna pluralisme, melainkan dalam mewujutkan masyarakat yang multikultural adalah berangkat dari pemahaman pluralisme menuju multikulturalisme.

James William, memaparkan

multikulturalisme adalah: "system of thought that recognizes more than one ultimete principle”.(Baidi, 2016) Sedangkan H.A.R. Tilaar menjabarkan, pengertian tradisional multikulturalisme memiliki dua ciri utama, pertama: kebutuhan terhadap pengakuan (the need of recognition) dan kedua: legistimasi keragaman atau pluralitas budaya. (Lasijan, 2014). Pada pemaparan tersebut jelas multikulturalisme adalah mengiring masyarakat pada memahami, menerima dan mengakui dengan menghormati dan toleransi akan martabat manusia hidup dalam komunitas dengan kebudayaanya masing masing dan kesederajatan yang sama. Krisis akan pengakuan disadari adalah akar dari ketimpangan dari berbagai bidang kehidupan yang kerapkali 
menimbulkan konflik dan ketidak amanan dalam kehidupan. Hingga Dengan pengakuan tersebut setiap perbedaan tidaklah dipandang sebagai persoalan namun menjadi suatu kekayaan dan dengan pengakuan, setiap individu merasa dihargai dan bertangung jawab untuk hidup bersama dalam komunitasnya.

Membahas tumbuhnya multikulturalisme di Indonesia tidak terlepas dari pembahasan akan sejarah kemerdekaan Indonesia, kesadaran akan keberagaman masyarakat Indonesia yang kaya akan budaya, beragam kepercayaan, bahkan kemajemukan secara kultur dan geografisnya telah tertanam dan telah menjadi modal awal dan disadari betul oleh Fonding Faher dalam membangun Bangsa Indonsia dengan Idiom negara "Bhineka Tunggal Ika”. Namun kesadaran akan keberagaman nyatanya belum sepenuhnya dipahami, selogan idiom bangsa belum benar terserap dalam realitas kehidupan. Hal ini di sadari dengan sistem monokulturalis yang diadopisi pemerintahan Orde Baru dengan nama stabilitas untuk developmentalism yang tidak lagi relevan dan justru menghancurkan dan menghilangkan local cultural geniuses dan menjatuhkan kegentaran konflik serta disintigrasi sosialbudaya lokal.(Mahfud, 2016)

Sehingganya

lahirlah

multikulturalisme sebagai isu setelah tumbangnya massa Orde Baru dan terdeklarasinya Reformasi, multikulturalisme diyakini mampu memulihkan dan memperekat kembali integrasi bangsa. Semasa orde baru yang mengunakan politik kebudayaan yang seragam dengan kekuatan yang mengikat keanekaragaman adalah politik sentaristik atau semata mata otoriter atas kekuasaan pemerintah yang berkuasa, dianggap sangat tidak lagi relevan dengan keadaan di massa revormasi dengan pesatnya globalisasi. Maka multikulturalisme bukan sebagai idiologi dokrinitas politik praktis yang dijalankan oleh otoritas pemerintah kekuasaan melainkan menjadikannya cara pandang kehidupan manusia, membangun kesadaran keberagaman Indonesia menjadi suatu yang utuh, kuat dan dengan upaya berdialog satu sama lain sekecil apapun minoritas berhak hidup setara dengan mayoritas, sekecil apapun perbedaan harus dihormati sehingga keberagaam yang disebut ke-Indonesiaan dapat dibangun.

Multikulturalisme tidak secara sepontanitas menghilangkan dan menghapuskan kekacauan bangsa akan konflik pergesekan ke-multikultural-an yang ada. Pemahaman akan bentuk masyarakan yang pulural sepenuhnya sudah difahamai sebagian besar masyarakat bahwa manusia tercipta dengan sangat beragam, baik secara fisiknya maupun selainnya, namun semangat hidup kolektif antar masyarakat masih sangat minus dan belum dapat menerima realitas perbedaan yang ada baik secara budaya, kepercayaan, etnis, suku, ras, dan sosialnya. Dengan masih banyaknya kalangan kalangan narsisme yang meramaikan isu isu konflik akibat keberagaman dan ke-multikulturalan. Nalar nalar kolektif masyarakat masih dibumbui dengan katupan tempurung logosentrisme hegemonik yang serat akan kecurigaan, prasangka, kebencian dan reduksi dari kelompok diluar dirinya. Hal ini menandakan belumnya terinternalisasi maksimal nilai-nilai multikulturalisme dalam jiwa masyarakat yang sangat penting untuk terus di suarakan dan ditanamkan. Dalam membangun dan mensosialisasikan multikulturalisme sebagai upaya pewujutan masyarakat yang rukun dalam kemultikultural-an hadirlan pendidikan 
multikultural sebagai rekayasa sosial yang dipandang sangat epik dan strategis untuk internalisasi nilai-nilai multikulturalisme kepada seluruh elemen masyarakat.

2. Perkembangan

Pendidikan

Multikultural di Indonesia

Pendidikan multikultural adalah proses pengembangan seluruh potensi manusia yang menghargai pluralitas dan heterogonitas sebagai bentuk konsekuensi dari keragaman baik agama, budaya, etnis, dan suku.(Naim, 2008) Secara definisi para ahli mendefinisikan secara beragam namun tetap menetapkan kebudayaan pada posisi yang sama yakni mencakup keberagaman menjadi poni dalam objek studi dalam pembelajaran.

Halnya James Banks (1993:3) pendidikan multikultural adalah ide gagasan, gerakan dan pembaharuan dalam pendidikan yang mencakup kepercayaan dan penjelasan yang menerima, mengakui dan menilai pentingnya keragaman budaya dan etnis dalam gaya kehidupan masyarakat baik secara sosial, individu, kelompok dan negara.

Farid Hanum (2005) menjelaskan pendidikan multikultural secara sederhana dimaknai sebagai pendidikan yang mengajarkan peserta didik untuk mampu menerima perbedaan, kritikan, dan memiliki rasa empati dan toleransi pada sesama tanpa memandang golongan, status sosial, gender, dan kemampuan akademik.

Hal ini senada dengan yang dikemukakan Coirul Mahfud (2016) yang menarik rumusan pendidikan multikultural sebagai study keaneka ragaman kultur, hak asasi manusia dan pengurangan atau penghapusan berbagai model prasangka buruk dalam upaya membangun kehidupan masyarakat yang adil dan damai.

Dalam perkembanganya, pendidikan multikultural di Indonesia yang berangkat dari ide multikulturalisme pada ambang angin reformasi setelah runtuhnya orde baru pendidikan multikultural dihembuskan dengan semangat demokrasi untuk menjunjung keberagaman dalam kesetaraan yang sama. Dalam kontek pendidikan yang dipercaya menjadi sebuah sistem yang paling berpengaruh dalam membentuk rekayasa sosial dalam kehidupan masyarakat sekaligus dipandang sebagai sistem media dalam internalisasi nilai nilai untuk menata kehidupan yang adil dan tentram.

Namun sampai dengan dewasa ini, pendidikan multikultural masih tak lebih dari wacana baru yang banyak digaungkan baik melalu pemerintahan dan para ahli dan kalangan terpelajar. Toleransi yang menjadi nilai kursial yang termaknai dalam pendidikan multikultural masih diadopsi sebagai bentuk ego-sentisme, yaitu suatu sikap mentoliransi orang lain untuk dirinya sendiri yang pada akhirnya tidak menjadikan toleransi sebagai suatu sikap membangun perdamaiaan dan hidup rukun secara berdampingan namun terjebak pada sikap acuh tak acuh (indifference).(Mahfud, 2016)

Pendidikan multikultural di Indonesia lain dengan pendidikan multikultural yang digaungkan oleh bangsa Barat, hal ini dilatar belakangi tidak lain adalah latar belakang keberagaman kultur dan kondisi yang jelas berbeda. Pendidikan multicultural di Indonesia mendasarkan pada Humanis-Religius, yakni pada asasasas nilai Pancasila, berbeda halnya dengan pendidikan multikulturaal di Dunia Barat yang mendasari pada prinsip-prinsip persamaan hak dan kebebasan (liberalism) yang merupakan sejarah warisan peradaban Barat yang sekuler. (Rukiyati, 2012) Maka dalam dasar Humanis-Religius pada pendidikan multicultural di Indonesia yang 
mencerminkan pada sila sila Pancasila, salah satunya pada sila pertama tentang Ketuhanan Yang Maha Esa. Mencerminkan bangsa Indonesia yang dibangun dengan ketuhanan dan kesadaran akan pluralitas agama dan budaya akan tetap mampu membangun bangsa Indonesia pada kesejakteraan dan kerukunan bangsa.

Johan C. Bock, dalam Education and Development: A Conflik Meaning (1992), memaparakan peranan pendidikan diantaranya : 1) memasyarakatkan idiologi dan nilai nilai sosial kultur bangsa, 2) mempersiapkan tenaga kerja yang siap menuntaskan kemiskinan, kebodohan, dan mendorong perubahan sosial, dan 3) meratakan kesempatan dan pendapatan. (Zamroni, 2002)

Dan dalam Undang-Undang Nomor 20 tahun 2003 tentang system Pendidikan Nasional, pasal 3 disebutkan: "Tujuan pendidikan nasional adalah mengembangkan potensi peserta didik agar menjadi manusia yang beriman dan bertakwa kepada Tuhan Yang Maha Esa, berakhlak mulia, sehat, berilmu, cakap, kreatif, mandiri, dan menjadi warga negara yang demokratis serta bertanggung jawab."

Sedang Paul Gorski (2010) menrincikan pada 3 tujuan pendidikan multikultural yakni 1) menghilangkan diskriminasi dan menyetarakan pluang dalam pendidikan untuk seluruh peserta didik untuk sama sama dapat mengembangkan potensinya dalam belajar, 2) menjadikan peserta didik mencapai prestasinya dengan potensinya, dan 3) melalui pendidikan mewujudkan peserta didik yang sadar dan peduli akan sosial masyarakat baik lokal, nasional dan global. (Lionar dan Agus, 2019)

Dengan ini jelas kolerasi antaran fungsi dan tujuan pendidikan nasional dengan hadirnya pendidikan multikultural bagi pengembangan bangsa Indonesia dalam urgensisnya menginternalisasi nilainilai multikulturalisme untuk mewujutkan perdamaian dan kerukunan dalam kehidupan yang plural dan beragam.

Pendidikan multikultural di Indonesia ditilik secara yuridis, telah banyak tertuangkan dan dijabarkan dalan Undang Undang Sitem Pendidikan Nasional tahun 2003, terkhusus pada pasal 4 ayat 1 yang mengatur akan prinsipprinsip penyelenggarakan pendidikan dengan menekankan akan keragaman kultur masyarakat dengan muatan nilai-nilai multikultural. (Mahfud, 2016)

Dalam UU Pasal 4 No.20 tahun 2003

Sistem Pendidikan Nasional dijelaskan bahwasanya prinsip prinsip penyelengarakan pendidikan adalah dengan demokratis, anti deskriminatif, mengagungkan hak asasi manusia, nilai keagamaan, nilai kultur, serta kemajemukan dan pluralitas bangsa. (Suryana dan Rusdiana, 2015)

Oleh karena itu konsep pendidikan multikultural yang mengusung pluralisme dan multikulturalisme dalam keberagaman dalam kesederajatan menghantarkan pada sebuah program pendidikan yang menghadirkan lingkungan belajar ganda kepada peserta didik yakni pendidikan yang memberikan kesesuaiaan kebutuhan dasar akan akademiks dan sosial peserta didik. Sehingga pendidikan multikultural diarahkan pada pencapaian pencapaian kompetensi yang mengandung nilai nilai yang menjadi pokok internalisasi multikulturalisme kepada peserta didik melalui pendidikan multikultural, diantaranya adalah : 1) Mengembangkan kompetensi akademik standar dan dasar yang mencakup didalamnya tentang nilai nilai; persatuan, kesatuan, demokrasi, keadilian, kebebasan, persamaan derajat, 
dan saling menghargai dalam pluralitas dan keberagaman. 2) Mengmbangkan kompetensi sosial yang mencakup didalamnya menumbuhkan pemahaman akan latar belakang budaya baik dalam dirinya dan juga budaya orang lain dalam masyarakat. 3) Mengembangkan kompetensi akademik yang mencakup didalamnya isu-isu dan problematika keseharian dengan proses demokratis dan atau inquiri dialogis. Dan 4) Membantu mengonseptualisasikan masyarkat yang diharapkan demokratis, dan pluralis dengan kesederajatan.

3. Interpretasi Al-quran dalam Muatan Nilai -Nilai Pendidikan Islam Berbasis Multikultural

Al-Quran sebagai pedoman hidup umat Islam yang diakui sebagai rahmatal lil alamin, diturunkan sebagai petunjuk hidup bukan hanya umat Islam tapi keseluruhan umat manusia. Hal ini sebagaimana Allah berfirman dalam QS. Al-Baqarah :2:185 “....diturunkannya AlQuran sebagai petunjuk bagi manusia dan penjelasan-penjelasan mengenai petunjuk itu....". Tidak terkecuali dalam kontek keberagaman dan kemajemukan manusia yang telah Allah ciptakan sebagai sunnatullah sebagaiman Allah berfirman dalam QS. Al-Hujurat aya 13, perbedaan hadir untuk dapat saling kenal mengenal dan tidak ada yang membedakan diantara manusia kecuali ketaqwaan kepada Allah SWT.

Dalam sebuah keberagaman, dewasa ini konflik dan isu agama serta rasisme menjadi suatu yang masih tetap hangat. Kontekstualitas atau interpretasi dalam Al-Quran akan nilai nilai multikultural dalam sebuah rangkaian tujuan pendidikan multikultural sebagai suatu upaya realisasi perwujutan Al-Quran sebagai pedoman dan petunjuk hidup manusia yang senantiasa bersingungan dan membahas persoalan kehidupan. Banyak ayat yang menjelaskan akan kemultikultural dan keberagaman manusia diantaranya dalam Qs. Al-Hujurat ayat 1113 yang menuangkan akan nilai nilai pendidikan multikultural.

Nilai adalah suatu konsep dasar yang sangat penting yang melekat pada sesuatu dan bernilai dalam kehidupan manusia.( Adisutio, 2012) Dan menurut Kontowijoyo, nilai adalah sesuatu yang dijunjung tinggi, yang memberi warna dan menjiwai tindakan seseorang. Sehingga nilai menjadi suatu yang memberikan makna pada hidup, yang memberi acuan, titik tolak, dan tujuan hidup. Menurut Farida Hanum muatan nilai nilai dalam pendidikan multikultural adalah berupa nilai demokrasi, nilai humanisme, dan nilai pluralisme. Dan nilai nilai pendidikan Islam berbasis multikultural diantaranya adalah : 1)Nilai Andragogi 2)Nilai Perdamaian, 3)Nilai Inklusivisme, 4)Nilai Kearifan, 5)Nilai Toleransi, 6)Nilai Humanisme, dan 7)Nilai Kebebasan.

Nilai nilai pendidikan Islam berbasis multikultural tersebut diantaranya dapat kita temui dalam intepretasi ayat AlQuran yakni dalam QS. Al-Hujurat ayat 1113. Nilai nilai pendidikan multikulturan yang terkandung dalam Qs Al-Hujurat ayat 11-13 diantaranya adalah :

1) Nilai Perdamaian

Perdamaian adalah kehidupan yang diimpikan semua manusia baik perdamaian dalam individu, kelompok, dan negara yang jelas multikultural. Menanamkan dan membumikan nilai perdamaian adalah bagian dari missi dan tujuan Agama Islam yang disebut sebagai Rahmatal lil aalamin. Dalam makna nilai perdamaian yang terkandung dalam pendidikan multikultural yang ter-interpretasi-kan dalam Tafsir Al- 
Azhar diantaranya tercatat dalam QS. Al Hujurat ayat 11, Hamka mengambarkan tentang peringatan dan nasihat sopan santun dalam pergaulan orang yang beriman. "Janganlah suatu kaum mengolok olok kaum yang lain." Mengolok-olok adalah bagian dari perkataan yang keji, sedang perkataan yang keji timbul dari budi yang rendah dan jiwa yang hina, maka dalam makna ini menjauhkan diri dari sikap yang keji dengan mengolok-olok dan merendahkan diri, karna bagian dari itu adalah $a s b a b$ dan akibat terjadinya perpecahan dan saling dendam kesumat.(Hamka: 2007) Dalam suatu riwayat di ceritakan bahwa ada salah satu seorang sahabat yang mencela dan menghinakan orang musyrik/non muslim namun beliou melarangnya dalam sabdanya: "Janganlah kamu cela mereka. Karena sesungguhnya tidaklah akan terlepas mereka itu dari perkataanmu, tetapi kamu telah menyakiti hati yang hidup. Cuma mulut mencela-ceka itu amat busuknya" (HR. Ibnu Abi Dunya). (Hamka, 2007)

Dalam hadits diatas, bagaimana Rasulullah melarang sikap budi rendah yakni mencela dan mengolok olok manusia sekalipun ia adalah orang yang tidak beriman, karna dengan mencela dan mengeluarkan celaan berupa perkataan atau tindakan berupa gerakan bibir, menertawakan, dan sebagainya yang membuat orang lain merasa malu dan direndahkan adalah merupakan bagian dari mengolok-olok yang tidak akan memberikan faedah dan tak lain hanya akan menyakiti orang lain, menimbulkan perpecahan serta merusak budi sendiri. Dengan mengolok-olok dan menghinan sebagai satu sabab timbulnya konflik dan hilangnya ke tentraman dalam sebuah hubungan dan permuatan keji tersebut pula digambarkan sebagai suatu bentuk mengolok olok dan mencelakakaan diri sendiri, menghilangkan ketentraman pada diri sendiri. Maka dilanjutkan dengan "Dan janganlah kamu mencela diri sendiri", Hamka men-kolerasi-kan dalam tafsirnya dengan QS. Al Hujmazah :1

"Neraka wailun bauat setiap orang yang suka mencederai dan mencela orang lain"

Inilah kolerasi persatuan yang sesungguhnya ditawarkan dalam ayat tersebut, menyakiti saudaranya adalah sama halnya menyakiti diri sendiri, mengolokolok orang lain sama halnya mengolokolok dan menjelekkan serta mencelakakan diri sendiri, karena lama kelamaan tukang hasut dan hasung, fitnah, dan menyebarkan berita busuk, mencela, dan memaki itu tidaklah akan membuat senang hati orang yang menerimanna kalau oarang yang menerimannya itu memiliki akal budi. Maka dalam perkara ini Hamka menjelaskan ayat tersebut adalah turunan adab dari makna ayat sebelumnya yakni pada ayat 6 .

Dalam hal ini diterangkan nilai perdamaian dapat terintepretasikan dengan ayat tersebut tentang larangan mengolokolok sebagai suatu asbab awal timbulnya perpecahan dan perselisihan yang mengusik kehidupan yang damai. Nilai Perdamian dalam QS. Al-Hujurat dilanjutkan dengan "Dan janganlah kamu pangil-memangil dengan gelar yang buruk" (Al-Hujurat :11). Larangan memangil dengan gelar yang buruk/julukan yang buruk dan tidak disukai (lebeling), dan menggantinya dengan nama yang lebih baik, sebagaimana Hamka dalam tafsirnya menyantumkan sebuah riwayat bagaimana Rasulullah memberikan tauladan menganti pangilan seorang sahabat menjadi pangilan yang lebih baik, dari Al-Khail (kuda) menjadi 
Al-Khair (yang baik). Dengan ini sebaikanya memangil orang dengan gelar yang buruk sebaiknya dihentikan dan dapat mengantinya dengan pangilan yang lebih baik, hal ini karena penukaran nama itu ada juga pengaruhnya bagi jiwa. Sehingganya dalam aplikasi dunia pendidikan nilai perdamaian dapat diperankan dengan tidak mengolok-olok dan merasa diri serba cukup dan sombong serta menghilangkan budaya lebeling/ julukan julukan yang tidak baik yang dari keduanya adalah asbab perselisishan dan perpecahan hingga hilngnya perdamaian dan keharmonisan hidup.

2) Nilai Kearifan

Dalam ajaran Islam, kearifan dapat dipelajari melalui ilmu sufi yakni suatu kebijakan atau kesucian hingga berarti suatu cara membersihkan hati dari kelakuan buruk. Mengenali nilai makrifat atau ajaran sufi, mengajari manusia untuk membersihkan nafsu, hati, dan jiwa melalui pendekatan esoteris melihat Allah tidak untuk diketahui tetapi untuk dicintai.(Yaya Suryana dan Rusdiana, 2015) Nilai kearifan menjadi bagian dari nilai yang hendak diterjemahkan dalam pendidikan multikultural, termasuk dalam pendidikan Islam, nilai kearifan terintepretasikan dalam Al-Quran diantaranya adalah dalam Qs. Al Hujurat ayat 12 yang menjelaskan ajaran sufisme yang memeritahkan untuk orang orang yang beriman untuk membersihkan hati, nafsu dan jiwanya dengan meninggalkan buruksangka, tajassus, dan ghibah.

"Wahai orang orang yang beriman,

jauhilah kebanyakan daripada buruk sangka" pada ayat tersebut Hamka menjelaskan dibalik dari larangan tersebut adalah ada pengaruhnya pada keimanan seorang yang beriman pastilah menjahui perkara perkara yang jelas dilarang diantaranya adalah, prasangka. Hamka menjelaskan prasangka adalah tuduhan yang bukan-bukan, prasangkaan yang tidak beralasan, hanya semata-mata tuhmat yang tidak pada tempatnya saja. Karena prasangka adalah bagian dari dosa, sebut tuduhan tuduhan yang tidak beralasan dan dapat memutuskan tali silaturahmi antara dua orang yang berbaik. (Hamka, 2001) Dalam tafsir tersebut Hamka pun menjelaskan dengan menterakan hadist Bukhari Muslim dan Abu Daud

"Sesekali janganlah kamu berburuksangka, karna sesungguhnya buruksangka adalah perkataan yang paling bohong. ..... dan jadilah kamu seluruh hamba Allah bersaudara."

Serta dalam hadits Ath-Thabrani : "Tiga macam membawa krisis bagi umatku, memandang kesialan, dengki dan jahat sangka.

Meninggalkan buruk sangka selain dari bagian ajaran terapi dalam tasawuf untuk membersihkan hati namun juga menjadi bagian solusi dalam problematika pendidikan multikultural yang masih terpaku pada nalar nalar kolektif masyarakat masih dibumbui dengan katupan tempurung logosentrisme hegemonik yang serat akan kecurigaan, prasangka, kebencian dan reduksi dari kelompok diluar dirinya, hingga kerapkali dalam menyikapi keberagaman dan perbedaan adalah hanya bagian dari mencari aman dan belum terciptanya kolektifitas dalam keberagaman.

Nilai makrifat selanjutnya dalam ayat ini dijelaskan dalam intepretasi larangan mencari-cari kesalahan orang lain dan larangan mengunjing. Hamka menerangkan bagaimana kebiasaan yang terpakai dalam kalangan kaum Komunis sendiri apabila mereka dalam merebut kekuasaan pada negara. Dalam perkara ini Hamka seolah mengingatkan pada beberapa 
tahun silam tentang kekritisan Indonesia pada awal awal kemerdekaan dimana Indonesia bertaruh dengan bangsa komunis. Larangan mengunjing yakni membicarakan aib dan keburukan orang lain sedang ia tidak hadir. Hamka menegaskan ini adalah perbuatan hina dan pengecut, dan bahwasanya mengunjing membicarakan keburukan sesorang ketika ia tidak hadir sama halnya memakan bangkai saudara yang telah busuk. Begitulah hinanya, maka seorang yang berimanan akan lebih bertanggung jawab, mengatakan di muka agar diubahnya kepada yang baik. (Hamka, 2001)

Dari ketiga larangan tersebut berburuk sangka, tajasus/mencari-cari kesalahan, dan ghibah/menggunjing menjadi intepretasi menuju nilai kearifan yang diartikan dalam ajaran tasawuf dalam Islam. Terdapat empat poin dalam makna ajaran Tasawuf dalam Islam yakni: 1)Membersihkan hati, 2)Belajar Agama, 3) Suka melaksanakan ibadah sholat berjamaah, dan 4) Berpakaiaan sederhanan dan zuhud. ( Ismail Hasan, 2014) Maka dalam ayat ini Allah menutup dengan kalimat "Dan bertaqwalah kepada Allah, sesungguhnya Allah adalah penerima tubat lagi maha penyayang” Hamka menguraikan dengan nilai nilai taubah, jikalau masih ada perangai tersebut dalam diri segeralah hentikan dan bertaubatlah dengan disertai penyesalan.

3) Nilai Inklusivisme

Inklusif adalah sikap berfikir terbuka dalam menghadapi berbagai perbedaan, baik perbedaan dalam pendapat, pemikiran, etnis, tradisi atau budaya sampai dengan kepercayaan atau agama. (Yakin, 2005) sedang inklusivisme adalah Meminjam istihan Alwi Shihab dalam jurnal konsep Internalisasi Nilai Inklusivisme atau tepatnya konsep Islam inklusiv haruslah dibangun dengan pondasi yang memiliki perspektif yang sama bahwa perbedaan adalah sunatullah, menghimpun pluralisme dan toleransi. (Shihab, 1998) Hingga Nilai Inklusivisme adalah nilai sikap terbuka dalam memahami keberagaman dan perbedaan sebagai sebuah kebenaran yang universal. Dengan nilai inklusivisme tersebut menjadikan sebuah jalan terjadinya dialog antar keberagaman yang bertujuan untuk menghindari kesalah faham atau mendahulukan kecurigaan dalam perbedaan dan terhindar adanya pembenaran absholut dan ekstrim dari bilik bilki perbedaan dan keberagaman.

Nilai inklusifisme dalam tafsir $\mathrm{Al}$ Azhar diantaranya termaktubkan dalam Qs. Al-Hujurat ayat 12 tentang larangan berburuk sangka dan ayat 13 tentang hakikat keberagaman yang telah Allah ciptakan sebagai sunnatullah yang ditujukan untuk saling berdialok kenal mengenal, yang berbunnyi:

"Hai manusia, sesungguhnya Kami menciptakan kamu dari seorang laki-laki dan seorang perempuan dan menjadikan kamu berbangsabangsa dan bersuku-suku supaya kamu saling kenal-mengenal..." (Qs. Al-Hujurat :13).

Pada ayat ini Hamka, menyampaikan pesan pada adab dan budi pekerti pergaulan kepada sesama manusia dengan tegas seruan yang Allah gunakan yakni "Hai Manusia" kemudian dilanjutkan dengan risalah hakikat penciptaan manusia yang memuat nilai egaliter/ kesamaan derajat dan yang berasal dari zat dan proses yang sama yakni pertama: Allah menciptakan manusia dari sosok laki-laki dan perempuan yang sama yakni Adam dan Hawa yang merupakan manusia pertama yang diciptakan Allah sebagai nenek moyang segenap 
manusia.(Hamka, 2009) Dan yang kedua: dengan penafsiran sedehana bahwa manusia diciptakan dari percampuran antara seorang laki-laki dan perempuan, dengan berkumpulnya dua mani dalam 40 hari lamanya yang disebut "nuthfah" kemudian 40 hari kemudian menjadi "alaqah" setelah tiga kali 40 hari dari "nuthfah" "alaqah" dan "mudhghah" maka jadilah manusia. (Hamka, 2009)

Dan pada makna pluralitas dengan pengalan ayat selanjutnya "dan menjadikan kamu berbangsa-bangsa dan bersuku-suku supaya kamu saling kenal-mengenal"

4) Nilai Toleransi

Toleransi berasal dari bahasa Inggris, yaitu tolerance yang bermakna sikap mengakui, membiarkan, dan menghormati. Dalam QS Al Hujurat makna interpretasi ayat nilai toleransi dalam pembelajaran multikulturan dituangkan dalam ayat 13 ,

"Wahai manusia, sesungguhnya Kami telah menciptakan kamu dari seorang lakilaki dan perempuan dan Kami jadikan kamu berbangsa bangsa dan bersuku suku supaya kenal mengenallah kamu”

Hamka menafsirkan tentang keberagama yang Allah ciptakan sebagai sunatullah suatu kepastian yang tidak dapat diingkari, Allah ciptakan berbangsa bangsa dan bersuku suku bahkan sampai pada perinciannya yang lebih kecil yaitu keluarga tidak untuk menjadikannya bertambah lama bertambah jauh, melainkan agar mereka saling kenal-mengenal akan keberagaman yang ada. Dengan saling mengenali keberagaman yang ada disinilah nilai toleransi tumbuh dengan memahami keberagaman yang ada. Toleransi bukan bermakna untuk dapat mengikuti seluruh keyakinan dan kepercayaan yang ada dalam keberagaman yang Allah ciptakan, namun toleransi diartkan sebagai nilai terbuka untuk mengakui ada kepercayaan dan keyakinan lain diluar dirinya dari bentuk pengakuan dari keberagaman sebagai suanatullah yang Allah anugrahkan kepada Alam semesta.

5) Nilai Humanisme

Nilai Humanisme atau nilai kemanusiaan adalah suatu nilai landasan dan tujuan dalam pendidikan yang merupakan bangian dari qodrati, kemanusiaan yang bersifat universal, global, yang mengatasi semua perbedaan baik suku, aliran, ras, kelompok, dan agama. (Suryana dan Rusdiana, 2015) Dalam tafsir Al-Azhar, Buya Hamka menjelaskan secara tersirat akan nilai Humanisme yang menjadi nilai pokok dalam penerapan pendidikan Multikultural yakni pada QS. Al Hujurat ayat 13 menafsirkan interpretasi dari makna taqwa dalam ayat tersebut.

"Sesungguh yang semulia-mulia kamu di sisi Allah ialah yang setaqwataqwa kamu" Hamka menerangkan bahwa pada ujung ayat ini menjelaskan bagi manusia bahwasannya kemuliaan sejati disisi Allah adalah mereka yang memiliki kemuliaan hati, kemuliaan budi, kemuliaan perangai dan ketaatan kepada ilahi. Pada ayat ini menuangkan nilai Humanisme yang menhapuskan perasaan setengah manusia yang menyatakan diri dapat lebih baik dari orang laian karena keturunan, atau asal ras dan bangsa.(Hamka, 2001) Dalam perkara ini seolah Allah mengingatkan pada tiap keberagaman adalah sunatullah dan untuk dapat saling menerima dan mengunggulkan jiwa kemanusiaan dengan nilai nilai humanisme antar sesama.

Intepretasi dalam makna taqwa dalam ayat ini, adalah sebaik baik manusia bagi mereka yang memiliki ketaqwaan mencerminkan baiknya agama sedang agama mengajarkan tentang banyak 
kemanusiaan, sedang baiknya budi, dan baiknya hati merupakan bagian naturalistik yang sebenarnya adalah fitrah lahir manusia dan nilai inilah yang meningkatkan gengsi dan martabat manusia.(Hamka,2001) Hingga dalam ujung ayat ini "Sesungguhnya Allah adalah Maha Mengetahui lagi Maha Mengenal" adalah jadi peringatan lebih dalam lagi bagi manusia yang telah silau matanya dan terpesona oleh urusan kebangsaan dan ke sukuan (keberagaman), maka banyak problematian dan kerusakan anatar manusia tak lain adalah hilangnya nilai humanisme yang fitrah dalam diri manusia, manusia terlupa pada nilai ketaqwaan hingga hidup berbangsa-bangsa dan bersuku suku bisa menjadi menjadi permusuhan dan peperangan.

Konsep Pendidikan Multikultural dalam QS. Al-Hujurat Ayat 11-13

Konsep multikulturalisme dijelaskan merupakan sebuah pandagan dunia yang merujuk pada implementasi kebijakan dalam menerima perbedaan atau pluralitas sebagai kesatuan, tanpa memperdulikan perbedaan budaya, etnik, gender, bahasa, ataupun agama .(H.A.R. 2004) Dalam QS. Al-Hujurat ayat 11-13 menerangkan konsep konsep pendidikan multikultural yang dapat terus dikembangkan yakni :

Pada ayat 11 menuangkan konsep menjauhkan diri dari sikap dan perbuatan mengolok-olok dan menghinakan diri sendiri. Mengolok-olok adalah bagian dari perkataan yang keji, sedang perkataan yang keji timbul dari budi yang rendah dan jiwa yang hina, maka dalam makna ini konsep menjauhkan diri dari sikap yang keji dengan mengolok-olok dan merendahkan diri, karna bagian dari itu adalah asbab dan akbibat terjadinya perpecahan dan saling dendam kesumat. Dalam suatu riwayat di ceritakan bahwa ada salah satu seorang sahabat yang mencela dan menghinakan orang musyrik/non muslim namun beliou melarangnya dalam sabdanya :
"Janganlah kamu cela mereka. Karena sesungguhnya tidaklah akan terlepas mereka itu dari perkataanmu, tetapi kamu telah menyakiti hati yang hidup. Cuma mulut mencela-ceka itu amat busuknya" (HR. Ibnu Abi Dunya).(Hamka 2007)

Dalam hadits diatas, bagaiman Rasulullah melarang sikap budi rendah yakni mencela dan mengolok olok manusia sekalipun ia adalah orang yang tidak beriman, karna dengan mencela dan mengeluarkan celaan berupa perkataan atau tindakan berupa gerakan bibir, menertawakan, dan sebagainya yang membuat orang lain merasa malu dan direndahkan adalah merupakan bagian dari mengolok-olok yang tidak akan memberikan faedah dan tak lain hanya akan menyakiti orang lain, menimbulkan perpecahan serta merusak budi sendiri.

Pada ayat 12 menuangkan konsep pendidikan multikultura menjauhkan diri dari berprasangka buruk, tajasus dan ghibah. Ketiga perbuatan dan sifat tersebut adalah perindukan dari makna ayat sebelumnya, Hamka dalam tafsirnya menegaskan perilaku berprasangka buruk, tajasus, dan ghibah hanya akan memutus dan memecah shilatu-rahim dan termasuk dari bagian cabang kemunafikan. Mencerminkan pada konsep pendidikan yang digagas oeh Hamka diantara lain dibangun atas dasr pemikiran: 1)Manusia, 2)Ilmu, dan 3)Akhlak. Dari dasar pemikiran tentang Manusia, manusia terdiri dari dikotomi yakni ruh dan jasad, ruh membutuhkan keimanan tempat bergantung sedang jasad mengandung akal dan perasaan maka pada kandungan perasaan inilah yang kemudian melahirkan kemanusiaan. Dalam konsep menjauhkan diri dari prasangka buruk, tajasus, dan ghibah merupakan bagian dari memenuhi kebutuhan dasar manusia dan melahirkan kemanusiaan dalam pendidikan.

Tantangan pendidikan multikultural dalam penerapan pendidikan termasuk dalam pendidikan Islam adalah masih 
berputar pada dua tantangan, pertama: Intoleransi dan fanatisme antar umat beragama dan keberagaman. Dan kedua: dikotomi dalam strata sosial hingga timbulnya konflik SARA. Pada konsep pendidikan multikultural yang ditawarkan dalam QS.Al-Hujurat ayat 11-12 adalah bagian menjawab tantangan pendidikan multikulturaal poin kedua, dengan menjauhkan diri dari sikap dan perbuatan mengolok-olok dan menghinakan diri sendiri serta menjauhkan diri dari prilaku prasangka buruk, tajasus, dan ghibah maka akan menghindarakan manusia pada dikotomi dalam strata sosial dan meminimalisisl tibulnya SARA antar keberagaman.

Dalam kedua ayat ini, merupakan bagian dari nasiat sopan-santun dalam pergaulan antar kaum yang beriman, menjadi refleksi dan transformasi besar bagi umat muslim di Indonesia yang merupakan bagian dari mayoritas, untuk memberi manfaat dan menjauhkan dari mafsadah dalam pergaulan dan menjadi percontohan bagi seluruh manusia dalam menyambung kedamain dalam pergaulan.

Pada ayat 13 menuangkan konsep menjalin persaudaraan, egaliter dan saling kenal-mengenal. Menjalin persaudaraan antar manusia tertuangkan dalam penafsiran Hamka pada awal ayat 13, yakni dua tafsir yang nyata dan tegas tentang penciptaan manusia yang merupakan berasal dari ayah dan ibu yang sama yakni Nabi Adam dan Siti Hawa, dan yang kedua tentang kejadian lahirnya manusia dari wujud asal yang sama yakni percampuran dua mani yang menjadi nutfah, 'alaqah, dan mudhghah. Dari ikatan inilah bahwa manusia adalah makhluk yang sama (egaliter) dan dengan karunia-Nya Allah hadirkan keberagaman dari warna-wajah hingga suku bahasa serta budayanya dari asal perbedaan iklim cuaca dan geografi buminya. Dan konsep saling kenalmengenal, menjadi turunanya dari tujuan diciptakan-Nya keberagaman manusia namun dari asal yang sama. Karna pangkal awal dari hadirnya konflik adalah perbedaan, namun tidaklah Allah ciptkan kebaikan dan keburukan melainkan sebagai ujian bagi manusia, maka pesan dari AlHujurat ayat 13 sebaik-baik manusia adalah yang bertaqwa yakni tau dan sadar akan keberagaman dan tujuanya hingga hadirlah toleransi yang didapat dengan saling kenalmengenal. Dalam konsep ini, pendidikan Multikultural sebagai ekspoilitasi perbedaan yang merupakan keniscayaan dan anugra yakni perbedaan dan keberagaman Agama, budaya, bahsa, sosial dan suku. Dalam konsep kenal-mengenal tidak sekedar didorong untuk tau tapi juga pengakuan, penerimaan, dan penghargaan akan keberagaman yang ada, dengan saling kenal-mengenal akan meberi pengetahuan dan kebermanfaatana.

Dengan kesadaran akan persaudaraan, egaliter dan dengan kenalmengenal, menjadi bagian jawaban untuk memecahkan tantangan pendidikan multikultural dalam penerapan pendidikan salah satunya dalam pendidikan Islam yakni menjaukan dari Intoleran dan fanatisme dalam agama dan keberagamna yang ada. yang kemudian menghubungkan pada orintasi pendidikan Multikultural yakni mencakup dari, kemanusiaan, kebersamaan, kesejakteraan, proposional, pluralitas dan heterogenitas serta anti hegemoni dan dominasi. Hingga terjawablah asal mula hadirnya konflik adalah perbedaan, namun dapat diredamkan dengan saling kenal mengenal dan persaudaraan.

Aplikasi Pendidikan Multikultural dalam QS. Al-Hujurat Ayat 11-13

Aplikasi dan peranan pendidikan multikultural dalam pendidikan Indonesia ditempatkan dalam tiga peranan, sebagai falsafah pendidikan, pendekatan pendidikan dan bidang kajian dalam pendidikan. Sehingga aplikasi pendidikan Multikultural dalam sekolah-sekolah telah lama di galakkan, dengan penggalakan prinsip prinsip pendidikan multikultural. Saluli dalam Pendidikan Multikultural dalam Islam menguraikan, prinsip dalam pendidikan multikultural adalah pendidikan 
yang mengajarkan keadilan, persamaan atau egaliter, bagi kedudukaan maupun kesempatan dalam belajar, lebih dari itu prinsip pendidikan multikultural juga menekankan dalam pengajaran toleransi dan menghargai orang lain.(Saluli 2019, 79)

Prinsip-prinsip tersebut tertuangkan dalam QS. Al-Hujurat ayat 11-13, dimana mampu dikembangkan dan diamplikasikan dalam bentuk pendidikan di sekolah dengan juga menanamkan nilai dan konsep pendidikan multikultural yang telah dijabarkan sebelumnya. Aplikasi pendidikan multikultural dalam ayat ini yakni;

Al-Hujurat ayat 11, pada ayat ini aplikasi pendidikan multikultural dapat dilangsungkan dengan menerapkan pendidikan yang menghindari sifat-sifat yang menyebabkan konflik, sepert mengolok-olok, prasangka buruk dan memangil dengan gelar yang buruk.

Al-Hujurat ayat 12 , pada ayat ini menerapkan pendidikan multikultural dengan metode islah yakni klarifikasi dan menghindarkan dari hal-hal yang menimbulkan salah faham. Metode islah yakni dengan menafikan hal-hal yang buruk sebagai damai pasif sebelum menetapkan hal-hal baik sebagai damai positif. Menjauhkan prasangka dan mengedepankan islah hingga tercegahnya sikap saling berburuk sangka, mengolokolok hingga konflik yang berkelanjutan antar hubungan sosial.

Dan Al-Hujurat ayat 13, pelaksanaan pendidikan multikultural dengan metode ta'aruf antar manusia dan keberagaman yang ada, dengan saling kenal mengenal. Dengan saling mengenal dapat saling mendapat pelajaran, pengalaman, dan saling memberi kebermanfaatan serta toleransi. Dalam aplikasi ini, pendidikan multikultural dialirkan secara intraduktif yakni dengan mengintegrasikan nilai-nilai pendidikan multikultural kedalam mata pelajaran pada setiap pembelajaran seperti bahasa, sains, ekonomi dan juga pembelajaran agama termasuk pendidikan
Agama Islam. Dengan terintegrasinya nilainilai multikultural dalam muatan matan mata pembelajaran menjadi sarana dalam penanaman nilai pendidikan multikultural secara kuantitatif dan kualitatif agar mudah dan tidak lagi berkultur teoristik namun lebih dapat diperluas dan difahami secara praktik dalam kehidupan.

Selain itu upaya upaya aplikasi pendidikan multikultural dengan jalan attaaruf memperkenalkan dan saling memahami antar keberagama yang terintegrasikan dalam mata pelajaran dalam proses pendidikan formal dianggap bagian stategi yang efektif dimana pendidikan adalah sistem rekayasa sosisal yang paling berpengaruh dalam mewarnai dan membentuk pola pikir dan prilaku seseorang dalam kehidupn sehari hari.

Namun dalam era pendidikan pandemi saat ini yang kemudian dibenturkan dengan berbagai keterbatasan dalam pembelajrana yang dilakukan secara virtual atau jarak jauh, hal ini sedikit mengikis dan mendegrasi dari baik muatan pembelajaran maupun aspek pembelajran yang hanya mampu tersampaikan secara langsung. Seperti halnya dalam pembelajaran daring saat ini yang berkrtergantungan dengan jejaring yang membawa pada pembelajaran mengudara dipandang hanya mampu secara efektif mentrasfer aspek kenowleg dan sedikit aspek afaktif yang dapat diserap peserta didik. Hal ini menjadi bagian permasalahan dan hambatan pendidikan multikultural pada massa kini.

Dalam hal ini muatan pendidikan multikultural dalam Q.S Al-Hujurat ayat 13 menjelaskan bagaiman Allah menciptakan Manusia berbangsa-bangsa dan bersukusuku untuk saling kenal-mengenal, dalam tafsirnya Hamka menurunkan bagaimana muara dari bangsa-bangsa dan suku suku adalah bagian dari keluarga, dan inilah pendidikan yang harusnya menjadi sorotan secara maksimal yakni pendidikan dalam keluarga.

Era pandemi seolah mengingatkan dan mengembalikan kita dengan cara pendidkan 
Rasulullah dimana belum dikenalnya lembaga-lembaga pendidikan yang disebut Pendidikan Formal yakni sekolah, namun saat itu Rasulullah mengajarkan Pendidikan Informal yang dimulai dari keluarga tempat pertama pendidkan muasal dan Pendidkan Non Formal yakni pendidikan dalam masyarakat berupa majelis-majelis ilmu yang pada massa Rasulullah di sebut dengan Baitul Arkom sebuah pendidikan yang dibangun dalam masyarakat yang pada massa itu bertempatan di rumah sahabat Arkom, dan juga bagimana Rasulullah mengajarkan dan menjadikan Masjid sebagai pusat peradaban dan juga pendidikan(Al-Mubarokfuri 2011). Hal ini kiranya perlu kembali disentuh dan menjadi perhatian khusus termasuk dalam integrasi nilai-nilai pendidikan multikultural yang sangan penting difahami, diakui, dan terus diakomodasikan dalam semangat multikulturalisme

\section{KESIMPULAN}

Berdasarkan dari hasil penelitian dan kajian pustaka yang telah penulis lakukan tentang nilai nilai pendidikan multikultural dalam Al-Quran perspektif tafsir Al-Azhar, maka penulis dapat mensimpulkan Al-Quran yang merupakan pedoman hidup umat manusia yang selalu memberikan solusi dan juga petunjuk yang tak kenal zaman telah juga menjawab problematika keberagaman dan kemultikulturalan yang dapat dijawantahkan dalam pendidikan yakni pada Intepretasi QS. Al-Hujurat ayat 11-13 yang memuat akan konsep, nilai, serta aplikasi pendidikan multikultural. Nilainilai pendidikan multikultural dalam AlQuran Surah Al-Hujurat ayat 11-13 menyebutkan 1)Nilai Perdamaian 2)Nilai Kearifan 3)Nilai Inklusivisme 4)Nilai Toleransi 5)Nilai Humanisme . Dan konsep pendidikan multikultural yakni 1)Konsep menjauhkan diri dari sikap dan perbuatan mengolok-olok dan menghina diri sendiri, 2)Konsep menjauhkan diri dari prasangka buruk, tajassus, dan ghibah,dan 3)Konsep menjalin persaudaraan dan saling kenal- mengenal. Serta metode atau aplikasi yang dapat diterapkan dalam pengembangan pendidikan multikultural, menghindari sifat sifat yang menyebabkan konflik, penerapan metode islah dan mendahulukan damai pasif sebelum damai positif, serta metode ta'aruf yang dapat diimplementasikan pada integrasi pembelajaran dalam tiap matapelajaran

\section{DAFTAR PUSTAKA}

Al-Farmawi, Abdul Hayy. (2012,) Metode Tafsir Maudu'i dan Cara Penerapanya. Jakarta: Raja Geafindo Persada.

Al-Mubarokfuri, Syafiyurrahman. ( 2011,) Shirah Nabawiyah. Jakarta: Umul Qura.

Amirin. (2012.) "Implementasi pendekatanpendidikan multicultural kontekstual berbasis kearifan local di Indonesia”. Jurnal Pembangunan Pendidikan : Fondasi dan Aplikasi. Vol 1 (3).

Baidi. (2016)

Pendidikan

Kewarganegaraan

Berbasik

Multikulturalisme Perspektif

Psikologi Sosial Islam. Yogyakarta: Deepublish.

Depertemen Agama RI. (2009,). Al-Quran dan Terjemah. Bandung: PT Sygma.

Hamka. (2005,). Tafsir Al-Azhar. Jilid I, Jakarta: PT Pustaka Panjimas.

Hamka. (2001,). Tafsir Al-Azhar. Juz 2526, Jakarta: PT Pustaka Panjimas.

Hamka. (2014,). Pribadi Hebat. Jakarta: Gema Insani.

Hamka. ( 2017,). Akhlakul Karimah. Jakarta: Gena Insani.

Irfani, Ranu Nada. (2017,). "Konsep Teori Belajar dalam Islam Perspektif Al Quran dan Hadits". Jurnal Ta'dib Vol. 6 (1). 
Hasan, Ismail. (2014,). “ Tasawuf: Jalan Rumpil Menuju Tuhan" Jurnal An Nuha Vol.1 (1).

Lasijan. (2014,). "Multikulturalisme dalam Pendidikan Islam". Jurnal TAPIs Vol.10 (02).

Mahfud, Choirul. (2010,). Pendidikan Multikultural. Yogyakarta: Pustaka Pelajar.

Naim, Ngainum dan Ahmad Sauqi. (2008,). PendidikanMultikultural, Konsep dan Aplikasi. Jogjakarta: Ar-RuzzMedia.

Rahmat. (2019,).

Pembelajaran Pendidikan Agama Islam Berwawasan Multikultural. Depok: Rajawali Press.

Rukiyati. (2012,). "Landasan dan Implementasi Pendidikan Multikultural di Indnesia”. Jurnal Humanika: MKU UNY Vol.12 (1).

Said, Muhammad Sameh. (2019,). Muhammad Sang Yatim. Bandung: Cordoba.

Saluli. (2019,). "Multikultural dalam Islam”. Jurnal Religi: Vol.17 (1).

Shihab, Qurais. (2017,). Tafsir Al-Misbah. Jilid 13, Cetakan VII, Jakarta: Lentera Hati.

Suparlan, Parasudi dkk. (2015,). Pendidikan Multikultural dan Revitalisasi Hukum Adat dalam Perspektif Sejarah. Jakarta: Kementrian Budaya dan Pariwisata.
Siyono, S. (2021). Multicultural Education at Pesantren (The Study of API ASRI Islamic Boarding School at Tegalrejo Magelang). Bulletin of Science Education, 1(1), 83-90.

Syafutra, S., Montessori, M., \& Suhono, S. (2021). Local Awareness in Making Social Integration of Society at Mendahara District. JMKSP (Jurnal Manajemen, Kepemimpinan, dan Supervisi Pendidikan), 6(2), 278-292.

Tilaar, H.A.R. (2004,). MultikulturalismeTantangan Tntangan Global masa depan dalam transformasi pendidikan nasional. Jakarta: Grasindo.

Tulus, Moh. (2014,). "Urgensi dan Signifikansi Pendidikan Islam Berwawasan Multikultural",Jurnal JPAI1/Januai-Juli.

UU Nomor 20 tahun 2003 tentangSistemPendidikan Nasional Pasal 3.

Welianto, Ari. "Kasus Kekerasan yang Dipicu Masalah Keberagaman di Indonesia" dalam www.kompas.com diunduh pada tanggal 06 Februari 2020

Zamroni. (2002,). Paradigma Pendidikan Masa Depan. Yogyakarta: BIGFAR Publisihing. 